\title{
Implementasi model pembelajaran berbasis proyek (project based learning) untuk meningkatkan aktivitas dan hasil belajar siswa
}

\author{
Martina Lona Jusita ${ }^{1}$ \\ Diterima 23 September 2019, Dipublikasikan 31 Oktober 2019 \\ Cpenulis (2019)
}

\begin{abstract}
Project-based Learning models provide opportunities for the teacher to manage learning improving project work. Students required to solve problems by applying the skills of researching, analysing, making, and presenting learning products based on real experience. The implementation of a project-based learning model has successfully increased learning activities and outcomes. Evidently from each cycle showed a significant increase. In the first cycle high learning activities were only 12 students (37.50\%) with a success rate of 58 in sufficient categories and a mean of 65 learning outcomes. The second cycle of learning activities increased to 22 students (68.75\%) with 71 succes rate in good categories and the average learning outcomes are 76. In the third cycle high learning activities reached 26 students $(81.25 \%)$ with an 80 level of success in the good category and the average learning outcomes 81 . The results of this action research reinforce the theoretical and empirical study of the effectiveness of PBL to improve activities and learning outcomes on material with characteristics at the analyzing level.
\end{abstract}

\section{Keywords}

Learning Activity, Learning Outcomes, Project Based Learning

\section{PENDAHULUAN}

Materi tentang pasar diajarkan pada jenjang SMP kelas VII memiliki tingkat berpikir pada jenjang analisis. Hasil dari pengukuran bekal ajar awal siswa menunjukkan bahwa $68 \%$ siswa masih butuh pendalaman materi dasar sebelum ke materi inti. Jika siswa dengan bekal ajar awal langsung mendapatkan materi inti, mereka akan kesulitan mengalami kesulitan belajar. Maka dari itu permasalahan pembelajaran ini membutuhkan perlakukan khusus agar mampu memahami materi dengan baik.

Model pembelajaran berbasis proyek (Project Based Learning selanjutnya disebut dengan PjBL) memberikan kesempatan kepada guru untuk mengelola pembelajaran dengan melibatkan kerja proyek. Model pembelajaran ini menggunakan proyek atau kegiatan sebagai sarana untuk mencapai kompetensi sikap, pengetahuan, dan keterampilan atau psikomotorik; di mana siswa dituntut untuk memecahkan masalah dengan menerapkan keterampilan meneliti, menganalisis, membuat, hingga mempresentasikan produk pembelajaran berdasarkan pengalaman nyata (Fathurrohman, 2015). Sedangkan Martinis (2013) menyatakan bahwa model pembelajaran ini bertujuan membentuk analisis pada masing-masing siswa atau peserta didik. Fokus pembelajaran pada prinsip dan konsep inti dari suatu disiplin ilmu serta melibatkan siswa dalam investigasi pemecahan masalah dan kegiatan tugas-tugas bermakna lainnya; selain itu

$1 \quad$ SMP Negeri 2 Ngantang Kabupaten Malang martinalonajusita@gmail.com 
memberikan kesempatan kepada siswa untuk bekerja dan menghasilkan suatu produk (Wena, 2009).

Dalam pembelajaran berbasis proyek guru menentukan batasan waktu dan batasan-batasan pembuatan proyek. Guru terus mendorong kerja siswa, serta setelah proyek terselesaikan memberikan umpan balik berupa ujian dan presentasi oleh siswa mengenai pembuatan proyek.

Keuntungan PjBL menurut Wena (2009) di antaranya adalah memotivasi siswa untuk menyelesaikan tugasnya dengan baik serta pentingnya kerja kelompok menuntut siswa mengembangkan dan mempraktikkan keterampilan komunikasi. Tidak kalah pentingnya bila diimplementasikan dengan baik akan memberikan siswa pembelajaran dan praktik pengelolaan proyek, mengalokasikan waktu dengan baik, sekaligus menggunakan perlengkapan untuk menyelesaikan tugas dengan efisien.

Penerapan PjBL dari kajian empiris menunjukkan mampu untuk meningkatkan hasil belajar pada rana kognitif. Keunggulan dari PBL adalah mampu untuk melibatkan siswa lebih banyak dalam pembelajaran (Nafiah dan Suyanto, 2014; Khotimah dan Salimi, 2017). Dengan keterlibatan mereka dalam pembelajaran akan meningkatkan pemahamannya dari makna pembelajaran (Soraya Mei dan Purnomo, 2019).

PjBL memiliki keunggulan proses pembelajaran yang dua arah. Proses pembelajaran yang efektif dapat terlihat dari adanya interaksi dua arah antara guru dengan siswa. Peserta didik adalah subjek yang memiliki kemampuan secara aktif mencari, mengolah, mengkonstruksi, dan menggunakan pengetahuan. Dalam proses pembelajaran siswa sebagai pusat pembelajaran atau student centered, sedangkan guru berperan sebagai fasilitator yang memfasilitasi peserta didik untuk aktif menyelesaikan masalah dan membangun pengetahuannya secara berpasangan ataupun berkelompok (kolaborasi antarsiswa). Dengan demikian perlu adanya pembelajaran aktif yang memungkinkan siswa berperan aktif dalam pembelajaran. Aktivitas belajar yang dilakukan siswa dapat merangsang dan mengembangkan bakat yang dimiliki, mampu berpikir kritis, dan dapat memecahkan masalah-masalah dalam pembelajaran.

Model pembelajaran berbasis proyek sebagai pembelajaran yang berpijak pada identifikasi dan analisis masalah yang ada di lingkungan sekolah. Melalui PjBL baik guru maupun siswa dilatih untuk mengembangkan berkolaborasi dan keterampilan berpikir kritis dan kreatif melalui proses penyelidikan (inquiry) dan pendekatan ilmiah (Khotimah dan Salimi, 2017). Model pembelajaran ini dirasa mampu diterapkan untuk mengatasi permasalahan pada proses pembelajaran pada materi pasar. Siswa dituntut lebih kreatif dalam menghasilkan produk berupa laporan penelitian yang sesuai dengan kompetensi yang diharapkan.

Menurut Sardiman (2014) bahwa prinsip belajar adalah berbuat atau melakukan kegiatan untuk mengubah tingkah laku. Tidak ada belajar kalau tidak ada aktivitas. Aktivitas belajar merupakan kegiatan mentransformasikan pengetahuan, sikap, dan keterampilan. Pengetahuan tersebut harus diperoleh melalui pengamatan sendiri, pengalaman sendiri, penyelidikan sendiri, dengan fasilitas yang ada. Dengan demikian siswa yang ikut berpartisipasi dalam proses pembelajaran dapat mengembangkan cara-cara belajar, belajar dalam perencanaan, pelaksanaan, dan penilaian proses belajar itu sendiri.

Keunggulan PjBL untuk meningkatkan aktivitas dan hasil belajar siswa menjadi pijakan penting untuk penelitian tindakan ini. Hasil empiris menunjukkan bahwa mampu untuk meningkatkan komunikasi dua arah dalam pembelajaran (Nafiah dan Suyanto, 2014; Khotimah 
dan Salimi, 2017). Oleh karena itu tujuan dari penelitian tindakan ini adalah untuk meningkatkan aktivitas dan hasil belajar melalui penerapan PBL.

\section{METODE}

Penelitian yang dilakukan adalah Penelitian Tindakan Kelas, karena peneliti berusaha memahami apa yang terjadi sambil terlibat dalam sebuah proses perbaikan dan perubahan (Wiriatmadja, 2009). Peneliti berpartisipasi langsung dalam penelitian mulai tahap awal hingga akhir. Subjek penelitian adalah siswa kelas VII-D SMP Negeri 2 Ngantang Tahun Pelajaran 2018/2019 sejumlah 32 orang. Jumlah siswa laki-laki 15 dan perempuan sejumlah 17 orang. Waktu penelitian dilakukan mulai minggu ketiga Februari 2019 sampai dengan minggu keempat Maret 2019.

Prosedur penelitian meliputi: (1) tahap pratindakan, dan (2) tahap pelaksanaan tindakan yang terdiri dari tiga siklus. Setiap siklus dilakukan perencanaan (plan), pelaksanaan (action), observasi (observation), dan refleksi hasil tindakan (reflection).

Langkah-langkah kegiatan selengkapnya diawali dengan menyiapkan instrumen penelitian dan Rencana Pelaksanaan Pembelajaran (RPP). Selanjutnya dalam pelaksanaan pembelajaran materi Pasar selama berlangsungnya proses melakukan pengamatan dan dokumentasi data-data yang berkaitan dengan aktivitas dan hasil belajar. Siswa melakukan tugas secara kelompok dan setelah selesai mempresentasikan hasilnya. Langkah terakhir adalah melakukan refleksi untuk melihat hasil pelaksanaan pembelajaran; yang dapat dijadikan bahan refleksi untuk menganalisis data serta menyimpulkannya. Hasil kesimpulan sebagai bahan acuan untuk merencanakan tindakan pada siklus berikutnya atau jika sudah mencapai kriteria tindakan tidak perlu diulang kembali. Target penelitian adalah 24 orang menunjukkan aktivitas belajar yang tinggi, penilaian tugas 75 , dan tes hasil belajarnya mencapai 75 sehingga rerata hasil belajarnya 75. Persentase keberhasilan tindakan mencapai 76 dalam kategori baik. Siklus Penelitian Tindakan Kelas yang dilaksanakan model spriral dari Kemmis dan Taggart (Hopkins, 1993) sebagai berikut.

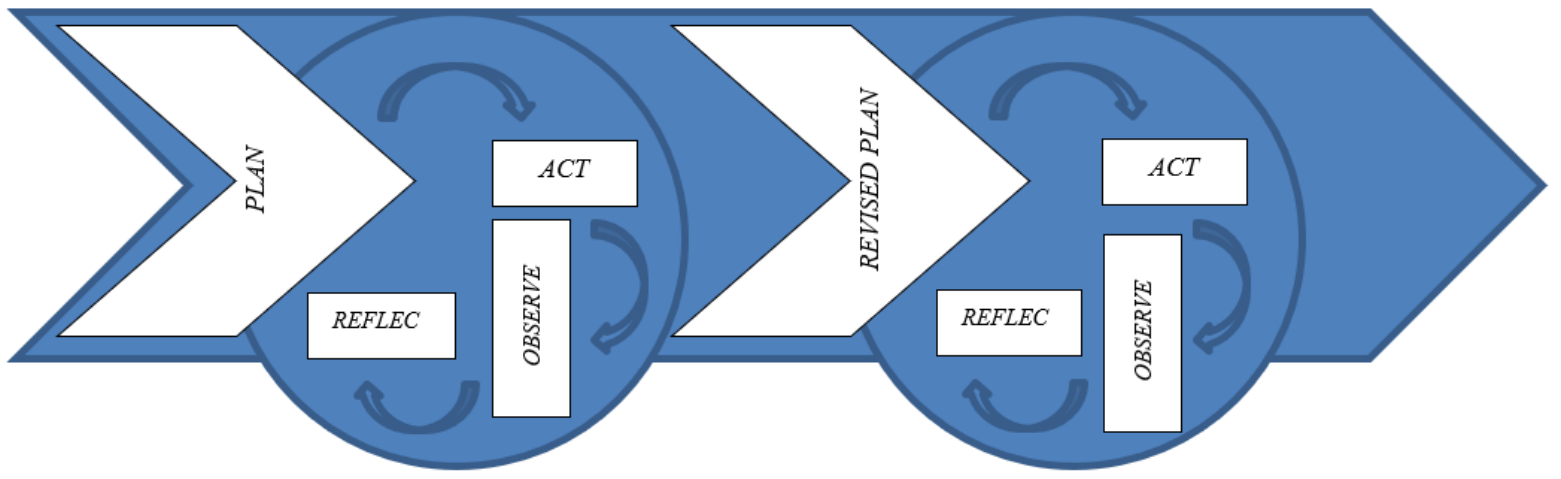

Gambar 1. Siklus Penelitian Tindakan Kelas (Hopkins, 1993)

\section{HASIL DAN PEMBAHASAN}

Berdasarkan observasi awal aktivitas belajar siswa dalam kategori rendah dengan rerata 32. Sejumlah 22 siswa $(68,75 \%)$ menunjukkan aktivitas belajar rendah dan hanya 10 orang $(31,25 \%)$ yang aktivitas belajarnya tinggi. Hal ini berpengaruh terhadap hasil belajarnya, dengan rerata hanya mencapai 53 dalam kategori rendah. Sejumlah 25 orang $(78,12 \%)$ menunjukkan hasil belajar di bawah Kriteria Ketuntasan Minimal (KKM). 
Setelah dilakukan tindakan dengan menggunakan model pembelajaran berbasis proyek (Problem Based Learning) pada Siklus I aktivitas belajar siswa mengalami sedikit peningkatan dibandingkan saat observasi awal. Hanya 20 orang $(62,50 \%)$ menunjukkan aktivitas belajar rendah; sedangkan 12 orang $(37,50 \%)$ sudah menunjukkan aktivitas belajar tinggi. Taraf keberhasilan tindakan mencapai 58 dalam kategori cukup.

Dari hasil observasi, kelemahan pada siklus I adalah kejelasan tahap pembelajaran yang masih belum dipahami oleh siswa. Oleh karena itu perbaikan skenario pembelajaran pada siklus I adalah untuk memberikan petunjuk belajar yang lebih jelas dalam bahan tayang untuk meningkatkan kadar keterbacaannya.

Pada Siklus II mengalami peningkatan hanya 10 orang $(31,25 \%)$ menunjukkan aktivitas belajar rendah dan sejumlah 22 orang $(68,75 \%)$ yang menunjukkan hasil belajar tinggi. Keberhasilan tindakan mencapai 71 dalam kategori baik. Dari hasil siklus II ini, perlakukan untuk mengatasi masalah pembelajaran sudah baik dan sesuai. Karena masih belum mencapai kriteria tuntas yang sudah ditentukan, maka perlakuan dilakukan sekali lagi untuk memastikan efektivitas tindakan.

Hasil dari siklus III melampaui target sejumlah 6 orang $(18,75 \%)$ saja yang menunjukkan aktivitas belajar rendah dan sejumlah 26 orang $(81,25 \%)$ menunjukkan aktivitas belajar tinggi dengan rerata persentase keberhasilan tindakan mencapai 80 dalam kategori baik. Dengan demikian penggunaan model pembelajaran berbasis proyek (Problem Based Learning) dapat meningkatkan aktivitas belajar.

Seiring dengan peningkatan aktivitas belajar dari siklus ke siklus, hasil belajarnya mengalami peningkatan secara signifikan. Rerata hasil belajar pada Siklus I mencapai 65 dalam kategori cukup. Siklus II meningkat menjadi 76 (kategori baik), dan Siklus III rerata menunjukkan 80 (kategori baik) (Gambar 2).

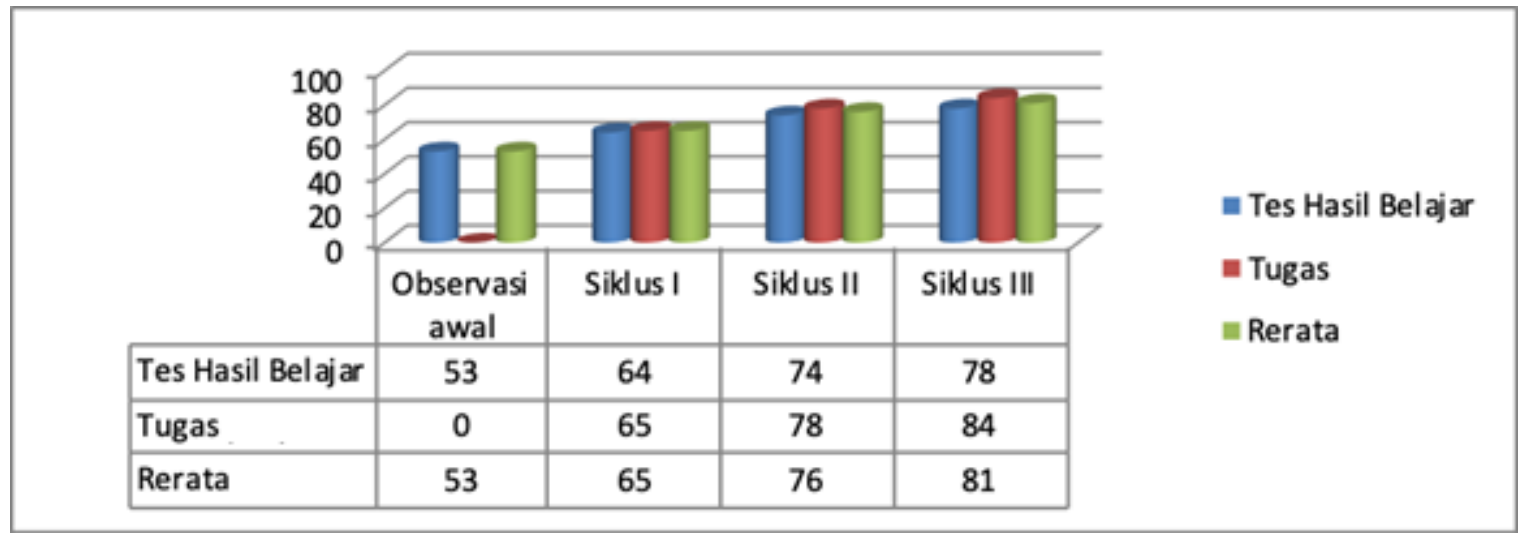

Gambar 1. Hasil belajar pada siklus I-III

Hasil penelitian pada Siklus I aktivitas belajar hanya sedikit mengalami peningkatan disebabkan sebagian besar kelompok tidak membuat perencanaan dan jadwal penyelesaian proyek dengan baik. Sehingga sesampai di lokasi hanya melihat-lihat dan bertanya sekadarnya. Masing-masing anggota kelompok melakukan observasi pasar secara mandiri tidak secara berkelompok, sehingga hasilnya sangat beragam. Pedoman wawancara belum disiapkan; oleh karenanya data yang diperoleh tidak lengkap. Penyusunan laporan sebagai tugas proyek berupa produk tidak sempurna, dengan demikian tidak dapat dipresentasikan secara maksimal. Terkesan masing-masing kelompok enggan untuk mempresentasikan hasil laporan akibat 
belum siap. Hanya satu dari enam kelompok yang membuat perencanaan, jadwal, dan pedoman wawancara dengan cukup baik. Berdasarkan temuan pada Siklus I aktivitas dan hasil belajar dalam kategori rendah; maka perlu diadakan perbaikan pada Siklus II.

Pada Siklus II mulai menunjukkan peningkatan. Salah satu penyebab adanya penyusunan ulang anggota kelompok dengan harapan mampu meningkatkan kerja sama antaranggota. Masing-masing kelompok sudah menyusun perencanaan, jadwal, pedoman wawancara dan laporan yang lebih baik. Keterlibatan anggota kelompok dalam menyelesaikan tugas proyek belum maksimal. Hanya tiga kelompok yang menunjukkan aktivitas tersebut. Ketika presentasi terlihat hanya empat kelompok yang "siap", sedangkan dua lainnya tidak berani mempresentasikan hasilnya karena "sedikit lebih siap". Aktivitas dan hasil belajar menjadi kategori baik akan tetapi belum mencapai target penelitian. Akan tetapi aktivitas belajar belum sesuai target sejumlah 24 orang yang menunjukkan aktivitas belajar tinggi serta taraf keberhasilan belum mencapai 75 . Untuk hasil belajarnya meskipun rerata sudah melampaui target; akan tetapi dari hasil tes hasil belajarnya yang masih di bawah target sedangkan tugas proyek sudah sedikit melampaui target. Untuk itu perlu diadakan perbaikan lagi pada Siklus III.

Perbaikan pada Siklus III adalah mengoptimalkan keterlibatan masing-masing anggota kelompok dalam menyelesaikan tugas proyek. Saat presentasi masing-masing kelompok berlomba untuk tampil terlebih dahulu karena sudah siap semuanya. Aktivitas dan hasil belajar pada Siklus III sudah melampaui target penelitian dengan kategori baik. Pencapaian tersebut sebagai akibat proses pembelajaran lancar dan kondusif.

Peningkatan aktivitas dan hasil belajar siswa pada materi pasar membuktikan bahwa PjBL efektif. Keefektifannya pada penelitian tindakan ini dihasilkan dari penyesuaian pemberian petunjuk belajar yang lebih jelas (Yulianto, Fatchan dan Astina, 2017; Surya, Relmasira dan Hardini, 2018). Informasi yang jelas akan mempermudah siswa memahami maksud instruksi kerja proyek yang dirancang oleh guru (Rasyid, 2019). Berdasarkan hasil penelitian tindakan ini, PjBL sesuai untuk mengatasi permasalahan aktivitas dan hasil belajar pada materi dengan ranah kognitif tingkat analisis.

\section{SIMPULAN}

Berdasarkan hasil penelitian membuktikan bahwa implementasi model pembelajaran berbasis proyek (Problem Based Learning) mampu meningkatkan aktivitas dan hasil belajar. Terbukti dari masing-masing siklus menunjukkan peningkatan secara signifikan. Aktivitas belajar pada Siklus I yang semula hanya 12 siswa (37,50\%) yang menunjukkan aktivitas belajar tinggi dengan taraf keberhasilan 58 dalam kategori cukup, meningkat menjadi 22 siswa $(68,75 \%)$ pada Siklus II dengan keberhasilan tindakan mencapai 71 dalam kategori baik. Pada Siklus III meningkat menjadi 26 orang $(81,25 \%)$ yang menunjukkan aktivitas belajar tinggi dengan persentase keberhasilan mencapai 81 dalam kategori baik.

Hasil belajarnya mengalami peningkatan secara signifikan pula, yang ditandai dengan rerata pada Siklus I mencapai 65 yang berasal dari tes hasil belajar 64 dan tugas proyeknya 66 dalam kategori cukup. Siklus II meningkat menjadi 76 yang berasal dari tes hasil belajar 74 dan tugas proyeknya 78 dalam kategori baik. Akhirnya pada Siklus III rerata menunjukkan 81 yang berasal dari 78 untuk tes hasil belajar dan tugas proyeknya 84 dalam kategori baik. Hasil penelitian tindakan ini menguatkan kajian teoritis dan empiris efektivitas PBL untuk meningkatkan aktivitas dan hasil belajar pada materi dengan karakteristik pada tingkat menganalisis. 
Volume 4 Nomor 2, Oktober 2019: hal 90 - 95

\section{DAFTAR PUSTAKA}

Fathurohman, M. 2015. Model-model Pembelajaran Inovatif. Yogyakarta: Ar-Ruzz Media.

Hopkins, D. 1993. A Teacher's Guide to Classroom Research. Philadelphia: Open University Press.

Khotimah, K. and Salimi, M. (2017) Penerapan model problem based learning untuk meningkatkan hasil belajar, KALAM CENDEKIA, 5(1).

Martinis, Y. 2013. Desain Pembelajaran Berbasis Tingkat Satuan Pendidikan. Jakarta: Referensi.

Nafiah, Y. N. and Suyanto, W. (2014) Penerapan model problem-based learning untuk meningkatkan keterampilan berpikir kritis dan hasil belajar siswa.

Rasyid (2019) Penerapan model pembelajaran project based learning untuk meningkatkan hasil belajar mahasiswa | Rasyid | Journal of Vocational and Technical Education (JVTE), Journal of Vocational and Technical Education. Available at: https://journal.unesa.ac.id/index.php/JVTE/article/view/4346 (Accessed: 31 October 2019).

Sardiman. 2014. Interaksi dan Motivasi Belajar Mengajar. Jakarta: Rajawali Press.

Soraya Mei, L. and Purnomo, A. (2019) 'Membangun empati siswa melalui bermain peran pada materi konflik sosial kelas VIII C SMP Lab UM', Jurnal Teori dan Praksis Pembelajaran IPS. State University of Malang (UM), 4(1), pp. 7-14. doi: 10.17977/um022v4i12019p007.

Surya, A. P., Relmasira, S. C. and Hardini, A. T. A. (2018) 'Penerapan model pembelajaran project based learning (PjBL) untuk meningkatkan hasil belajar dan kreatifitas siswa kelas III SD Negeri Sidorejo Lor 01 Salatiga', Jurnal Pesona Dasar, 6(1). doi: 10.17529/PEAR.V6I1.10703.

Wena, M. 2009. Strategi Pembelajaran Inovatif Kontemporer. Jakarta: PT Bumi Aksara.

Wiriaatmadja, R. 2009. Metode Penelitian Tindakan Kelas. Cetakan kedelapan. Bandung: PT Remaja Rosdakarya.

Yulianto, A., Fatchan, A. and Astina, I. K. (2017) 'Penerapan model pembelajaran project based learning berbasis Lesson Study untuk meningkatkan keaktifan belajar siswa', Jurnal Pendidikan: Teori, Penelitian, dan Pengembangan, 2(3), pp. 448-453. doi:

10.17977/JPTPP.V2I3.8729. 